\title{
Ester Prodrugs of Cyclic 1-(S)- [3-Hydroxy-2-(phosphonomethoxy)propyl]-5-azacytosine: Synthesis and Antiviral Activity
}

\author{
Marcela Krečmerová, ${ }^{*}, \dagger$ Antonín Holý, ${ }^{* \dagger}$ Radek Pohl, ${ }^{\dagger}$ Milena Masojídková, ${ }^{\dagger}$ Graciela Andrei, ${ }^{\ddagger}$ Lieve Naesens, ${ }^{\ddagger}$ Johan Neyts, ${ }^{\ddagger}$

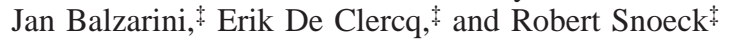 \\ Gilead Sciences and IOCB Research Centre, Institute of Organic Chemistry and Biochemistry, Academy of Sciences of the Czech Republic, \\ Flemingovo nám. 2, CZ-166 10, Prague 6, Czech Republic, and Rega Institute for Medical Research, Katholieke Universiteit Leuven, \\ Minderbroedersstraat 10, B-3000 Leuven, Belgium
}

Received June 19, 2007

Reaction of 1-(S)-[3-hydroxy-2-(phosphonomethoxy)propyl]-5-azacytosine (1) with dicyclohexylcarbodiimide and $N, N$,-dicyclohexyl-4-morpholinocarboxamidine in dimethylformamide at elevated temperature afforded the corresponding cyclic phosphonate 2 , that is, 1-\{[(5S)-2-hydroxy-2-oxido-1,4,2-dioxaphosphinan-5-yl]methyl $\}$-5-azacytosine. Compound $\mathbf{2}$ exerts strong in vitro activity against DNA viruses, comparable with activity of parent compound $\mathbf{1}$. Transformation of $\mathbf{2}$ to its tetrabutylammonium salt followed by reaction with alkyl or acyloxyalkyl halogenides enabled us to prepare a series of structurally diverse ester prodrugs: alkyl (octadecyl), alkenyl (erucyl), alkoxyalkyl (hexadecyloxyethyl), and acyloxyalkyl (pivaloyloxymethyl) (3-6). The introduction of an alkyl, alkoxyalkyl, or acyloxyalkyl ester group to the molecule resulted in an increase of antiviral activity; the most active compound was found to be the hexadecyloxyethyl ester $\mathbf{5}$. The relative configuration of the diastereoisomer trans-6 was determined using H,H-NOESY NMR.

\section{Introduction}

Acyclic nucleoside phosphonates (ANPs) ${ }^{a}$ represent a key class of antiviral nucleoside derivatives. ${ }^{1}$ One of the most promising drug candidates of this group is cidofovir, 1-(S)-[3hydroxy-2-(phosphonomethoxy)propyl]cytosine (HPMPC). This compound, in clinical practice approved for the treatment of cytomegalovirus (CMV) retinitis in AIDS patients, has strong activity against virtually all types of DNA viruses. ${ }^{1,2}$ However, a dose-limiting side effect of this drug is its nephrotoxicity. Furthermore, in contrast to other ANP drugs, cidofovir is given by intravenous infusion, ${ }^{3}$ and orally applicable prodrugs are not available yet; their development is still in process. ${ }^{4}$ The unique activity of cidofovir combined with our effort for diminution of its side effects, improvement of its (oral) bioavailability, and general search for new biologically active compounds resulted in the development of various modified cidofovir derivatives. Recently we have described base-modified HPMPC analogs bearing various aliphatic substituents in positions C-5 and $N^{4} .5$ Unfortunately, these substitutions resulted in complete loss of antiviral activity. However, modification of the base moiety by introduction of an additional nitrogen atom proved successful.

* Corresponding authors. M.K.: phone, +420 220183475; fax, +420 220183560; e-mail, marcela@uochb.cas.cz. A.H.: phone, +420 220183384; fax, +420220183560; e-mail, holy@uochb.cas.cz.

Academy of Sciences of the Czech Republic.

Katholieke Universiteit Leuven.

a Abbreviations: ANP, acyclic nucleoside phosphonate; Bis(POC)PMPA, bis(isopropyloxycarbonyloxymethyl) ester of 9-(R)-[2-(phosphonomethoxy)propyl]adenine; Bis(POM)-PMEA, bis(pivaloyloxymethyl) ester of 9-[2-(phosphonomethoxy)ethyl]adenine; cHPMP-5-azaC, cyclic form of 1-(S)-[3-hydroxy-2-(phosphonomethoxy)propyl]-5-azacytosine; cHPMPC, cyclic form of 1-(S)-[3-hydroxy-2-(phosphonomethoxy)propyl]cytosine, DCC, $N, N^{\prime}$-dicyclohexylcarbodiimide; DMF, $N, N$-dimethylformamide; DMSO, dimethylsulfoxide; HCMV, human cytomegalovirus; HHV-6, human herpesvirus type 6; HPMPA, 1-(S)-[3-hydroxy-2-(phosphonomethoxy)propyl]adenine; HPMP-5-azaC, 1-(S)-[3-hydroxy-2-(phosphonomethoxy)propyl]-5-azacytosine; HPMPC, 1-(S)-[3-hydroxy-2-(phosphonomethoxy)propyl]cytosine; HSV-1, herpes simplex virus type 1; HSV-2, herpes simplex virus type 2; iPr, 2-propyl; PMEA, 9-[2-(phosphonomethoxy)ethyl]adenine; PMPA, 9-(R)-[2-(phosphonomethoxy)propyl]adenine; POM, pivaloyloxymethyl; VZV, varicella zoster virus.
In our previous paper, we described the synthesis of cidofovir analogs containing as a base component 5-aza- and 6-azacytosine. ${ }^{6}$ Whereas the 6 -aza derivative was virtually inactive, the 5-azacytosine analogue of cidofovir, 1-(S)-[3-hydroxy-2(phosphonomethoxy)propyl]-5-azacytosine (HPMP-5-azaC, 1, Figure 1), exerted strong activity against a broad spectrum of viruses: adenoviruses, poxviruses (vaccinia virus, cowpox virus, orf virus), herpes simplex (type 1 and 2) virus, varicella-zoster virus (VZV), and human cytomegalovirus (HCMV). Compared to cidofovir, its antiviral activity data [based on $50 \%$ effective concentration $\left(\mathrm{EC}_{50}\right.$ values)] was similar or in some cases higher, and the antiviral selectivity index [ratio of $50 \%$ cytotoxic concentration $\left(\mathrm{CC}_{50}\right)$ to $\mathrm{EC}_{50}$ ] was 2- to 16 -fold higher than $(S)$ HPMPC. ${ }^{6}$

Compound $\mathbf{1}$ has two negative charges in the molecule and, hence, its bioavailability is expected to be very low (similarly as for cidofovir). Generally, oral bioavailability of nucleoside phosphonates is improved by conversion of free phosphonic acids to neutral lipophilic esters. Thus, for example, adefovir, 9-[2-(phosphonomethoxy)ethyl]adenine (PMEA), is transformed to bis(pivaloyloxymethyl) ester prodrug adefovir dipivoxil (bis(POM)-PMEA), ${ }^{7}$ a compound approved for the treatment of chronic hepatitis B. Similarly, tenofovir, 9- $(R)$-[2(phosphonomethoxy)propyl]adenine (PMPA) is clinically used as an anti-AIDS drug in the form of bis(isopropyloxycarbonyloxymethyl) ester, that is, tenofovir disoproxil (bis(POC)PMPA). ${ }^{8}$ Oral bioavailability of this ester is $>20 \%$ and antiviral effect in vitro is $>100$-fold higher than that of PMPA. During the past years, special attention has been paid to development of orally active prodrugs of HPMPC and its adenine counterpart, HPMPA, for their potential use against poxvirus infections including smallpox in case of a bioterrorist attack. Esterification of cidofovir can be performed at the level of the cyclic phosphonate. One possibility of such esterifications is represented by salicylate prodrugs. ${ }^{9}$ Another approach consists in preparation of lipid alkyl or alkoxyalkyl esters ${ }^{4,10}$ having about 20 atoms in the lipid chain. Introduction of various lipid alkoxyalkyl ester groups has recently been reported also for 


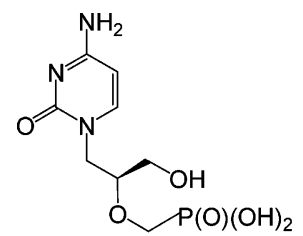

(S)-HPMPC (cidofovir)

Fure 1.

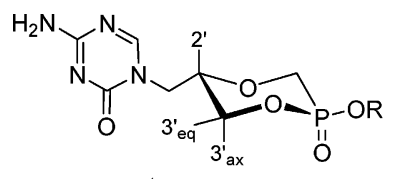

trans

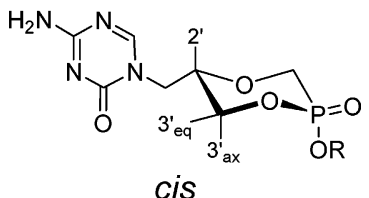

Figure 2.

9-(S)-[3-hydroxy-2-(phosphonomethoxy)propyl]adenine (HPMPA); in this case, active compounds were prepared as sodium salts of the appropriate phosphonate monoesters. ${ }^{11}$

This work follows up on our previous study dealing with acyclic 5-azacytosine nucleoside phosphonates and particularly 1-(S)-[3-hydroxy-2-(phosphonomethoxy)propyl]-5-azacytosine $^{6}(\mathbf{1})$. Discovery of its unique antiviral activity resulted in the necessity to focus on the following problems: (1) preparation of the cyclic form of 1-(S)-[3-hydroxy-2-(phosphonomethoxy)propyl]-5-azacytosine and (2) preparation of structurally diverse types of esters, optimization of these reactions from a synthetic point of view, antiviral screening of all newly prepared compounds in vitro and selection of the appropriate ester prodrugs for further in vivo evaluation.

\section{Chemistry}

Transformation of $\mathbf{1}$ to cyclic phosphonate $\mathbf{2}$ was realized by the action of dicyclohexylcarbodiimidide and $N, N$,-dicyclohexyl4-morpholinocarboxamidine in dimethylformamide at elevated temperature, the process being analogous to preparation of cyclic HPMPC. ${ }^{10}$ Subsequent esterification process including work up, isolation, and purification of products had to be developed with respect to alkali-labile character of 5-azacytosine compounds. This instability resulting in triazine ring cleavage is observed especially in aqueous alkaline solutions, ${ }^{12}$ strong bases used for reactions in dry aprotic solvents leave the triazine ring unattached. Therefore, we used cyclic lipid esters of $\mathbf{2}$ as final products for antiviral assays, in contrast to cidofovir of which the cyclic esters were subsequently hydrolyzed with sodium hydroxide to the corresponding monoesters. ${ }^{10}$ To assess the role of ester structure in antiviral activity, four diverse ester types were synthesized: alkyl (e.g., octadecyl), alkenyl (erucyl, that is, (Z)-docos-13-enyl), acyloxyalkyl (pivaloyloxymethyl), and alkoxyalkyl (2-(hexadecyloxy)ethyl). The most successful esterification method was reaction of tetrabutylammonium salt of 2 with alkyl bromides, e.g., octadecyl bromide, erucyl bromide, or hexadecyloxyethyl bromide giving compounds $3-5$ (Scheme 1). This reaction works excellently with tetrabutylammonium salt (prepared by neutralization of 2 with 1 equiv of tetrabutylammonium hydroxide), probably due to its good solubility in organic solvents; when another kind of salt (sodium or lithium salt) was used, no esterification occurred. Products obtained by this method usually still contain residual tetrabutylammonium salts (even after column chromatography), and therefore, final purification by appropriate HPLC technique or crystallization was always performed.

Besides this method, we also tried direct esterification of 2 with appropriate alcohol, for example, 2-(hexadecyloxy)ethanol.
The reaction performed in dimethylformamide in the presence of dicyclohexylcarbodiimide at elevated temperature afforded the desired 2-(hexadecyloxy)ethyl ester 5, but only in modest yield; due to mild reaction conditions, most starting compound 2 remained intact and could be recovered.

The attempts to prepare bis[(acyloxy)alkyl] ester prodrugs of 1 were inspired with methodology used for preparation of bis(POM)-PMEA consisting generally of the treatment of the appropriate chloromethyl (or iodomethyl) ether and $\mathrm{N}, \mathrm{N}$,dicyclohexyl-4-morpholinocarboxamidine with free phosphonic acid. ${ }^{13}$ In contrast to PMEA, 1 treated under such conditions with chloromethyl pivalate afforded a complex nonseparable mixture of the expected bis(POM) ester 7 and both diastereosomers of cyclic phosphonate 6 (Scheme 2) in a low overall yield. Yields and ratios of components were not reproducible. All effort for improvement of selectivity and yield of this reaction failed (e.g., substitution of chloromethyl pivalate with more reactive iodomethyl pivalate, use of starting phosphonate $\mathbf{1}$ in the form of lithium, pyridinium, or triethylammonium salt, variation of solvents, and temperature range). Therefore, we finally decided to develop the pivaloyloxymethyl ester prodrug not as bis(POM) ester 7 but similarly as in previous cases at the level of the cyclic phosphonate. Compound $\mathbf{2}$ was transformed to its tetrabutylammonium salt and then treated with chloromethyl pivalate in dry dioxane giving exclusively the desired POM ester 6 in very good yields (up 50\% after all purification processes).

Esterification of $\mathbf{2}$ introduces new chiral center into the molecule resulting in formation of diastereoisomeric esters $3-\mathbf{6}$. The ratio of diastereoisomers was 5:2 to 3:2 in favor of the less polar diastereoisomer. These diastereoisomeric mixtures were used for basic in vitro antiviral evaluation. Because pharmacokinetic properties are generally in close relation to geometry of the molecule, it would be useful to get insight into configuration of the phosphorus chiral center. For this purpose, NMR spectroscopy was used as the method of choice due to the fact that esters 3-6 are difficult to separate and crystallize in order to obtain crystals suitable for X-ray analysis. The HPLC separation was successful only in the case of small amounts of the erucyl derivative $\mathbf{4}$ and the less polar major diastereoiseomer of compound 6. Diastereoisomeric esters can accommodate two relative configurations trans and cis (Figure 2).

In the trans configuration, both azacytidine and OR moieties occupy equatorial positions on the six-membered ring in the chair conformation. On the other hand, cis configuration is used for azacytidine moiety in equatorial and OR group in axial position. The chair conformation can be unambiguously elucidated by inspection spin-spin coupling constants from ${ }^{1} \mathrm{H}$ NMR spectrum (Table 1).

The relative configuration was determined from $\mathrm{H}, \mathrm{H}-\mathrm{ROESY}$ spectrum of less polar major diastereoisomer $\mathbf{6}$, for which NOE contacts between protons from $\mathrm{OCH}_{2} \mathrm{O}$ from the ester moiety and $\mathrm{CH}_{2} \mathrm{P}$ from the six-membered ring (trans configuration) or $\mathrm{OCH}_{2} \mathrm{O}$ ester moiety and $\mathrm{CH}_{2} \mathrm{O}$ from the six-membered ring (cis configuration) could be observed. Therefore, relative configuration of the less polar major diastereoisomer $\mathbf{6}$ was determined as trans due to $\mathrm{NOE}$ between protons from $\mathrm{OCH}_{2} \mathrm{O}$ and $\mathrm{CH}_{2} \mathrm{P}$ (see Supporting Information- $\mathrm{H}, \mathrm{H}-\mathrm{ROESY}$ of trans6).

The relative configuration of other diastereoisomers $\mathbf{3}-\mathbf{5}$ can be determined by comparison of their ${ }^{31} \mathrm{P}\left({ }^{1} \mathrm{H} \mathrm{dec}\right) \mathrm{NMR} .{ }^{31} \mathrm{P}$ nucleus in less polar major diastereoisomers resonates at a higher magnetic field $(10.63-11.43 \mathrm{ppm})$ than in polar minor diastereoisomers $(12.56-13.60 \mathrm{ppm})$. Thus, it can be concluded that 
Scheme $1^{a}$<smiles>Nc1ncn(CC(CO)OCP(O)O)c(=O)n1</smiles>

1

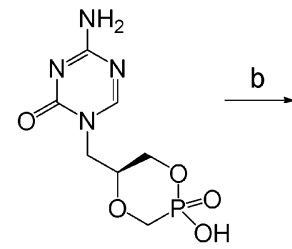

2

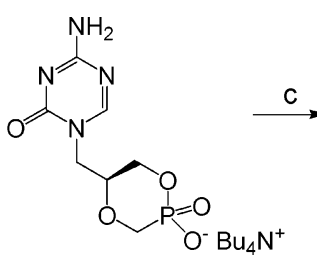

$\mathrm{O}^{-} \mathrm{Bu}_{4} \mathrm{~N}^{+}$

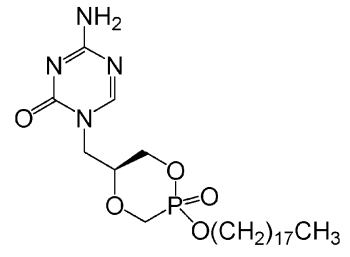

3

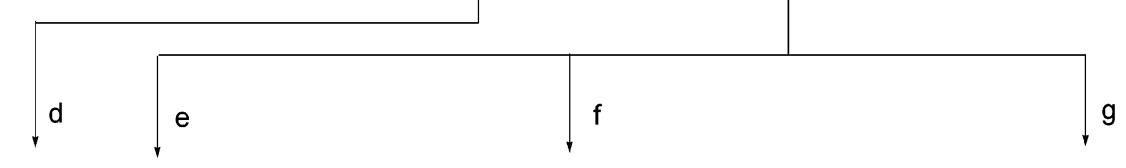

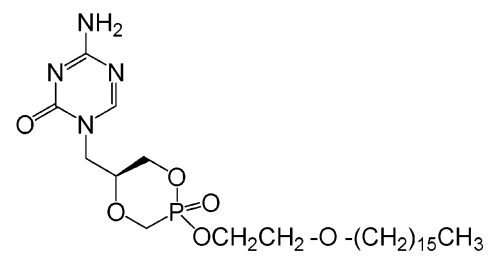

5

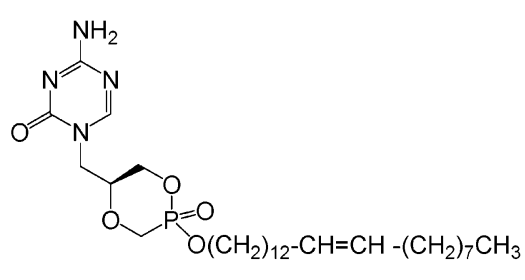

4

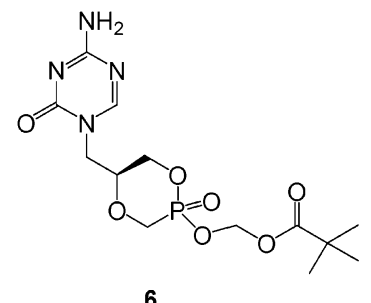

6

${ }^{a}$ Conditions: (a) DCC, $N, N$,-dicyclohexyl-4-morpholinocarboxamidine, DMF, $90^{\circ} \mathrm{C}$; (b) tetrabutylammonium hydroxide; (c) octadecyl bromide, dioxane, $95{ }^{\circ} \mathrm{C}$; (d) 2-(hexadecyloxy)ethanol, DCC, DMF, $110^{\circ} \mathrm{C}$; (e) hexadecyloxyethyl bromide, DMF, $100^{\circ} \mathrm{C}$; (f) erucyl bromide, DMF, $100{ }^{\circ} \mathrm{C}$; (g) chloromethyl pivalate, dioxane, $100{ }^{\circ} \mathrm{C}$

Scheme $2^{a}$

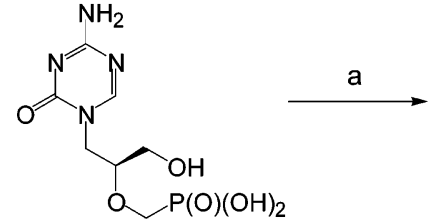

1

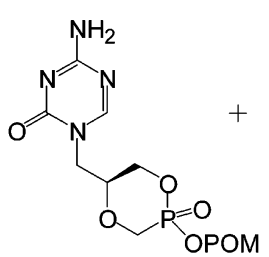

6<smiles>CO[Po](O)OCC(CO)Cn1cnc(N)nc1=O</smiles>

7

not separated

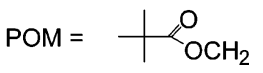

${ }^{a}$ Conditions: (a) chloromethyl pivalate, $N, N$,-dicyclohexyl-4-morpholinocarboxamidine, DMF, r.t.

Table 1. Experimental Spin-Spin Coupling Constants in Chair Conformation of Cyclic Phosphonate Esters 3, 4, and 6

\begin{tabular}{lcccc}
\hline \multicolumn{1}{c}{ ester } & $J\left(2^{\prime}, 3^{\prime} \mathrm{ax}\right)$ & $J\left(2^{\prime}, 3^{\prime} \mathrm{eq}\right)$ & $J\left(3^{\prime} \mathrm{ax}, \mathrm{P}\right)$ & $J\left(3^{\prime} \mathrm{eq}, \mathrm{P}\right)$ \\
\hline 3-trans & 10.5 & 2.3 & 1.7 & 17.2 \\
3-cis & 9.5 & 2.7 & 4.0 & 15.5 \\
4-trans & 10.7 & 2.1 & 1.6 & 17.3 \\
4-cis & 9.3 & 2.8 & 4.3 & 14.9 \\
6-trans & 10.5 & 2.3 & 1.4 & 17.3 \\
\hline
\end{tabular}

less polar major diastereoisomers have trans configuration whereas more polar minor diastereoisomers occupy cis configuration.

\section{Biological Activity}

The antiviral activity of the different compounds was evaluated against various DNA viruses (Table 2), RNA viruses, and retroviruses (Table 3 ) in cell culture. The spectrum of activity of the cyclic form of 1-(S)-[3-hydroxy-2-(phosphonomethoxy)propyl]-5-azacytosine (2) was comparable to that of HPMP-5azaC (1) and the reference compounds HPMPC and cHPMPC. Compound $\mathbf{2}$ was able to inhibit the replication of poxviruses (vaccinia virus), and different herpesviruses, including herpes simplex virus type 1 (HSV-1) and type 2 (HSV-2), thymidine kinase-deficient HSV-1 [acyclovir resistant $\left(\mathrm{ACV}^{\mathrm{r}}\right)$ ], varicellazoster virus (VZV), human cytomegalovirus (HCMV), and human herpesvirus 6 (HHV-6) with $\mathrm{EC}_{50}$ values in the range of $0.06-3.1 \mu \mathrm{g} / \mathrm{mL}$. Compound $2 \mathrm{did}$ not affect cell morphology or cell growth of HEL cells measured as, respectively, the minimum cytotoxic concentration (MCC) or the $50 \%$ cytostatic concentration $\left(\mathrm{CC}_{50}\right)$, up to a concentration of $100 \mu \mathrm{g} / \mathrm{mL}$ (highest concentration tested). This resulted in selectivity indices (ratio of $\mathrm{CC}_{50}$ to $\mathrm{EC}_{50}$ ) varying from $>47$ (vaccinia virus) to $>1500$ (HCMV). The potency of the new triazine analogues 1 and 2 was comparable to that of HPMPC and cHPMPC; however, HPMP-5-azaC and cHPMP-5-azaC proved to be approximately 2-fold less cytostatic for HEL cells than HPMPC and $\mathrm{cHPMPC}$, resulting in a superior selectivity. In the case of HHV-6, the cyclic form of 1-(S)-[3-hydroxy-2-(phosphonomethoxy)propyl]-5-azacytosine (2) proved to be 5-fold (HHV6A) and 13-fold (HHV-6B) less active than HPMP-5-azaC (1) in, respectively, human T-lymphoblast HSB-2 and MOLT-3 cells. Compound $\mathbf{2}$ proved to be more cytotoxic for MOLT-3 cells $(\mathrm{MCC}=33 \mu \mathrm{g} / \mathrm{mL})$ than for HSB-2 cells $(\mathrm{MCC}=200$ $\mu \mathrm{g} / \mathrm{mL})$.

When the different ester prodrugs, that is, alkyl (octadecyl), alkenyl (erucyl), alkoxyalkyl (hexadecyloxyethyl), and acyloxyalkyl (pivaloyloxymethyl) (3-6), were evaluated, the hexadecyloxyethyl (5) emerged as the most active one, with $\mathrm{EC}_{50}$ values in the range of $0.003-0.008 \mu \mathrm{g} / \mathrm{mL}$ for $\mathrm{HSV}$, 

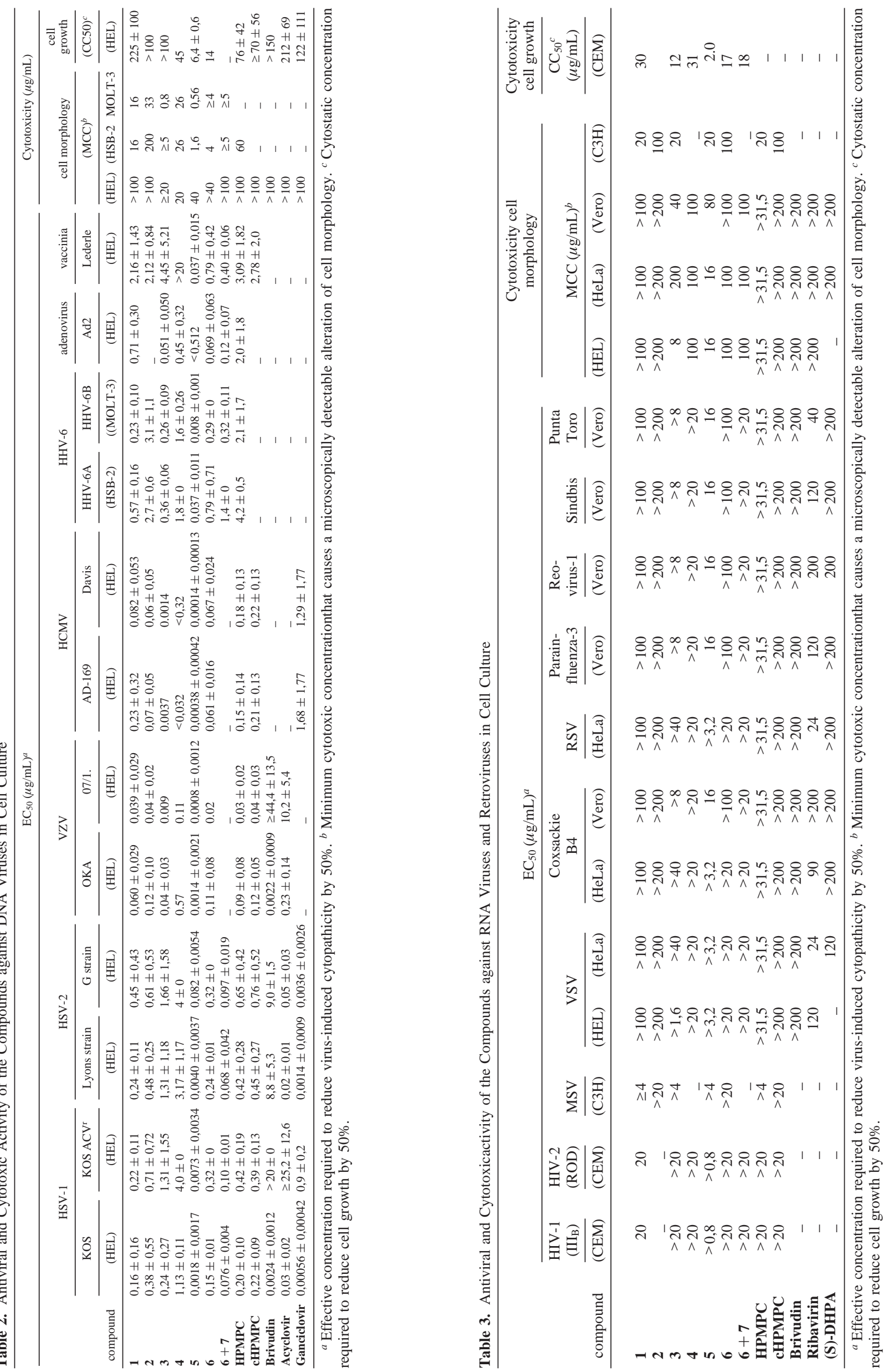
$\leq 0.0008-\leq 0.0014 \mu \mathrm{g} / \mathrm{mL}$ for $\mathrm{VZV}, \leq 0.00014-\leq 0.00038 \mu \mathrm{g} /$ $\mathrm{mL}$ (HCMV), $0.008-0.037 \mu \mathrm{g} / \mathrm{mL}$ for HHV-6, and $0.037 \mu \mathrm{g} /$ $\mathrm{mL}$ for vaccinia virus. This resulted in a 58- (vaccinia virus), 100- (mean for HSV strains), 123- (mean for VZV strains), to 250-fold (mean for HCMV strain) increase in antiviral activity when compared to cHPMP-5-azaC (2). Not only an improvement in the antiviral activity was observed for compound $\mathbf{5}$ but also an increase in selectivity. Thus, selectivity indices for compound 5 are 43 (HHV-6A), 70 (HHV-6B), 173 (vaccinia virus), 1160 (HSV), $\geq 5800$ (VZV), and $\geq 24600$ (HCMV), as compared to 74 (HHV-6A), 11 (HHV-6B), > 47 (vaccinia virus), $>180$ (HSV), >740 (VZV), and >1540 (HCMV) for compound 2.

Although a marked increase in antiviral potency was noted for the octadecyl ester (3) compared to compound $\mathbf{2}$ against $\mathrm{HCMV}\left(\mathrm{EC}_{50}=0.0014-0.0037 \mu \mathrm{g} / \mathrm{mL}\right)$, only a slight increase in activity against VZV $\left(\mathrm{EC}_{50}=0.04-0.009 \mu \mathrm{g} / \mathrm{mL}\right)$ or a decrease in potency against $\mathrm{HSV}$ ( $\mathrm{EC}_{50}$ ranging from 0.24 to $1.66 \mu \mathrm{g} / \mathrm{mL})$ and vaccinia virus $\left(\mathrm{EC}_{50}=4.45 \mu \mathrm{g} / \mathrm{mL}\right)$ was observed. Despite the fact that the octadecyl ester (3) did not affect cell growth up to a concentration of $100 \mu \mathrm{g} / \mathrm{mL}$, it produced an alteration of cell morphology at a concentration $\geq 20 \mu \mathrm{g} / \mathrm{mL}$.

The esterification of compound $\mathbf{2}$ to produce the erucyl prodrug (4) resulted in a loss of activity against vaccinia virus $\left(\mathrm{EC}_{50}>20 \mu \mathrm{g} / \mathrm{mL}\right)$ and no improvement or slight decrease in activity against HSV and VZV. However, compound 6 maintained a good potency against $\mathrm{HCMV}\left(\mathrm{EC}_{50}<0.032 \mu \mathrm{g} / \mathrm{mL}\right)$. The pivaloyoxymethyl ester $(\mathbf{6})$ showed $\mathrm{EC}_{50}$ values equivalent to those of compound 2 . A $\mathrm{CC}_{50}=14 \mu \mathrm{g} / \mathrm{mL}$ was recorded for compound 6, resulting in a decrease in selectivity when compared to compound 2. As expected, akin to $(S)$-HPMPC (cidofovir) or its 5-azacytosine analogue, none of the compounds (2-6) showed activity against RNA viruses or retroviruses (Table 3).

\section{Conclusion}

In conclusion, the cyclic form of the new antiviral, 1-(S)-[3hydroxy-2-(phosphonomethoxy)propyl]-5-azacytosine, was prepared, and general methodology for the preparation of its esters was worked out. The most active compound was found to be 2-(hexadecyloxy)ethyl ester of 1-\{[(5S)-2-hydroxy-2-oxido1,4,2-dioxaphosphinan-5-yl]methyl -5-azacytosine (5); the activity of ester prodrugs was decreasing in the order: 2-(hexadecyloxy)ethyl $>$ pivaloyloxymethyl $\approx$ octadecyl $>$ erucyl. Not only was the 2-(hexadecyloxy)ethyl ester the most active compound it was also the most selective one.

\section{Experimental Section}

Unless stated otherwise, solvents were evaporated at $40{ }^{\circ} \mathrm{C} / 2$ $\mathrm{kPa}$ and compounds were dried at $13 \mathrm{~Pa}$. Melting points were determined on a Kofler block and are uncorrected. Analytical TLC was performed on silica gel $60 \mathrm{~F}_{254}$ plates (Merck KGaA, Darmstadt, Germany); chromatographic systems are described in text. Preparative TLC was performed on silica gel $\mathrm{UV}_{254}$ (30$60 \mu$, Service Laboratories of IOCB, Prague). Column chromatography was performed on silica gel $60 \mu \mathrm{m}$ (Fluka). Reverse phase HPLC separations were performed on a Waters Delta 600 instrument with a Waters 2487 Dual $\lambda$ Absorbance Detector using columns XTerra $\mathrm{RP}_{18}(5 \mu \mathrm{m}, 3.9 \times 150 \mathrm{~mm}$, flow $1 \mathrm{~mL} / \mathrm{min}$, analytical column; $10 \mu \mathrm{m}, 10 \times 150 \mathrm{~mm}$, flow $5 \mathrm{~mL} / \mathrm{min}$, preparative column) and Luna Phenomenex C-18 (10 $\mu \mathrm{m}, 21 \times$ $250 \mathrm{~mm}$, flow $12 \mathrm{~mL} / \mathrm{min}$, preparative column). ${ }^{1} \mathrm{H}$ and ${ }^{13} \mathrm{C}$ NMR spectra were measured on a Bruker Avance 600 spectrometer $\left({ }^{1} \mathrm{H}\right.$ at $600 \mathrm{MHz},{ }^{13} \mathrm{C}$ at $151 \mathrm{MHz}$ ) or Bruker Avance 500 spectrometer

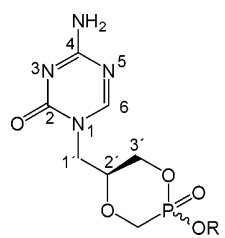

Figure 3. General numbering scheme for assignment of NMR signals.

$\left({ }^{1} \mathrm{H}\right.$ at $500 \mathrm{MHz},{ }^{13} \mathrm{C}$ at $\left.125.7 \mathrm{MHz}\right)$ in $\mathrm{CDCl}_{3}, \mathrm{D}_{2} \mathrm{O}$, DMSO- $d_{6}$ solutions (referenced to TMS, sodium 3-(trimethylsilyl)propane1 -sulfonic acid (DSS) or residual solvent signal). ${ }^{31} \mathrm{P}$ NMR spectra were measured on Bruker Avance 500 spectrometer $(202.3 \mathrm{MHz})$ in $\mathrm{CDCl}_{3}$ using $\mathrm{H}_{3} \mathrm{PO}_{4}$ as external standard. The numbering system for assignment of NMR signals is outlined in Figure 3. Mass spectra were measured on a ZAB-EQ (VG Analytical) spectrometer using FAB (ionization with xenon, accelerating voltage $8 \mathrm{kV}$, glycerol matrix) or by ESI technique.

Materials and Solvents. Most of the chemicals and ion-exchange resins (Dowex 1X2-400) were purchased from Sigma-Aldrich (Czech Republic). Dimethylformamide and dioxane were dried by distillation from $\mathrm{CaH}_{2}$ (DMF in vacuo) and stored over molecular sieves $4 \AA$ (DMF) or sodium (dioxane). Erucyl bromide ${ }^{14}$ and hexadecyloxyethyl bromide ${ }^{15}$ were prepared from the corresponding alcohols by the action of $\mathrm{PBr}_{3}$ or carbon tetrabromide. For erucyl bromide, the method using carbon tetrabromide is more convenient to avoid cis - trans isomerization of the double bond.

1-\{[(5S)-2-Hydroxy-2-oxido-1,4,2-dioxaphosphinan-5-yl]methyl \}-5-azacytosine (2). A suspension of $\mathbf{1}(200 \mathrm{mg}, 0.71 \mathrm{mmol})$, $N, N^{\prime}$-dicyclohexylcarbodiimide (DCC, $155 \mathrm{mg}, 0.75 \mathrm{mmol}$ ) and $N, N^{\prime}$-dicyclohexyl-4-morpholinecarboxamidine $(220 \mathrm{mg}, 0.75 \mathrm{mmol})$ in DMF $(5 \mathrm{~mL})$ was stirred at $85^{\circ} \mathrm{C}$ for $3 \mathrm{~h}$, then additional portions of DCC (20 mg) and $N, N^{\prime}$-dicyclohexyl-4-morpholinecarboxamidine (20 mg) were added and the heating continued for $2 \mathrm{~h}$ (till conversion was complete). The reaction course was monitored by TLC in system 2-propanol-25\% aqueous ammonia-water (7:1: 2 ), $R_{F}$ of the product: 0.45 . The reaction mixture was cooled to room temperature, diluted with water $(5 \mathrm{~mL})$, and applied onto a column of Dowex 1 (acetate form, $50 \mathrm{~mL}$ ). Elution was performed with water $(500 \mathrm{~mL})$, followed by $1 \mathrm{M}$ acetic acid $(200 \mathrm{~mL})$ and finally, the product was eluted with $1 \mathrm{M}$ formic acid. A product containing fraction was evaporated, the residue coevaporated with water $(4 \times 30 \mathrm{~mL})$. The crude product was finally purified by reverse phase HPLC: (Luna Phenomenex preparative C-18 column, isocratic elution with $2 \%$ aqueous methanol, $12 \mathrm{~mL} / \mathrm{min}$, retention time $10 \mathrm{~min}$ ). The product containing fraction was evaporated and dried in vacuo. Yield: $180 \mathrm{mg}, 97 \%$, white solid. ESIMS: 263 $(\mathrm{MH})^{+}(70), 525(2 \mathrm{MH})^{+}(100)$. HRMS (QTOF): For $\mathrm{C}_{7} \mathrm{H}_{12} \mathrm{~N}_{4} \mathrm{O}_{5} \mathrm{P}$ $\left(\mathrm{MH}^{+}\right)$calculated: 263.0545; found: 263.0543. ${ }^{1} \mathrm{H}$ NMR $(500$ $\left.\mathrm{MHz}, \mathrm{D}_{2} \mathrm{O}\right): 3.83\left(\mathrm{dd}, 1 \mathrm{H}, J_{\text {gem }}=14.2, J_{\mathrm{H}, \mathrm{P}}=1.7, \mathrm{CH}_{\mathrm{a}} \mathbf{H}_{\mathrm{b}} \mathrm{P}\right) ; 3.86$ $\left(\mathrm{dd}, 1 \mathrm{H}, J_{\mathrm{gem}}=14.6, J_{1} \mathrm{~b}, 2=8.3, \mathrm{H}-1^{\prime} \mathrm{b}\right) ; 3.97\left(\mathrm{dd}, 1 \mathrm{H}, J_{\mathrm{gem}}=\right.$ $\left.14.2, J_{\mathrm{H}, \mathrm{P}}=9.3, \mathrm{CH}_{\mathrm{a}} \mathrm{H}_{\mathrm{b}} \mathrm{P}\right) ; 4.02\left(\mathrm{~m}, 1 \mathrm{H}, \mathrm{H}-2^{\prime}\right) ; 4.18\left(\mathrm{dd}, 1 \mathrm{H}, J_{\mathrm{gem}}\right.$ $=14.6, J_{1^{\prime}} \mathrm{a}, 2$. $\left.=2.9, \mathrm{H}^{\prime} 1^{\prime} \mathrm{a}\right) ; 4.25\left(\mathrm{~m}, 2 \mathrm{H}, \mathrm{H}-3^{\prime}\right) ; 8.46(\mathrm{~s}, 1 \mathrm{H}, \mathrm{H}-6)$. ${ }^{13} \mathrm{C}$ NMR $\left(125.7 \mathrm{MHz}, \mathrm{D}_{2} \mathrm{O}\right): 46.57\left(\mathrm{CH}_{2}{ }^{\prime}{ }^{\prime}\right) ; 65.12\left(\mathrm{~d}, J_{\mathrm{C}, \mathrm{P}}=\right.$ $\left.144, \mathrm{CH}_{2} \mathrm{P}\right) ; 69.48\left(\mathrm{~d}, J_{\mathrm{C}, \mathrm{P}}=7, \mathrm{CH}_{2}-3^{\prime}\right) ; 72.83\left(\mathrm{~d}, J_{\mathrm{C}, \mathrm{P}}=7, \mathrm{CH}-\right.$ 2'); 147.41 (C-2); 159.52 (C-4); 162.30 (CH-6).

Esterification of 2 via Tetrabutylammonium Salt. General Procedure. Methanolic tetrabutylammonium hydroxide (1 M; 0.61 $\mathrm{mL} ; 0.61 \mathrm{mmol})$ was added to a solution of $2(161 \mathrm{mg}, 0.61 \mathrm{mmol})$ in absolute methanol $(50 \mathrm{~mL})$, the mixture stirred for $10 \mathrm{~min}$ in ultrasound bath and evaporated. The residue was coevaporated with toluene $(2 \times 20 \mathrm{~mL})$, dissolved in appropriate solvent $(5 \mathrm{~mL}$, dioxane for $\mathbf{3}$ and $\mathbf{6}$, DMF for $\mathbf{4}$ and $\mathbf{5}$ ), and stirred with alkyl bromide $(1.5 \mathrm{mmol})$ or chloromethyl pivalate $(5 \mathrm{mmol})$ at 95 $-100{ }^{\circ} \mathrm{C}$ for $3-6 \mathrm{~h}$ (TLC control). The reaction mixture was cooled to room temperature, diluted with methanol $(2 \mathrm{~mL})$ and evaporated. The residue was chromatographed on a column of silica gel (50 $\mathrm{mL})$ in a system of chloroform-methanol $(85: 15)$ and the product obtained thus finally purified by crystallization from methanol or HPLC separation. 
Octadecyl Ester of 1-\{[(5S)-2-Hydroxy-2-oxido-1,4,2-dioxaphosphinan-5-yl]methyl \}-5-azacytosine (3). Yield: $250 \mathrm{mg}, 80 \%$ of a white solid after crystallization from methanol. Anal. $\left(\mathrm{C}_{25} \mathrm{H}_{47} \mathrm{~N}_{4} \mathrm{O}_{5} \mathrm{P}\right) \mathrm{C}, \mathrm{H}, \mathrm{N}, \mathrm{P}$. ESIMS: $1051.0(2 \mathrm{M}+\mathrm{Na})^{+}(41), 537.3$ $(\mathrm{M}+\mathrm{Na})^{+}(64), 515.3(23)(\mathrm{MH})^{+}$. HRMS (QTOF): For $\mathrm{C}_{25} \mathrm{H}_{48} \mathrm{~N}_{4} \mathrm{O}_{5} \mathrm{P}$ $\left(\mathrm{MH}^{+}\right)$calculated: 515.3362; found: 515.3382.

Major diastereoisomer (trans): ${ }^{31} \mathrm{P}\left({ }^{1} \mathrm{H} \mathrm{dec}\right) \mathrm{NMR}(202.3 \mathrm{MHz}$, $\left.\mathrm{CDCl}_{3}\right)$ : 10.63. Minor diastereoisomer (cis): ${ }^{31} \mathrm{P}\left({ }^{1} \mathrm{H} \mathrm{dec}\right) \mathrm{NMR}$ (202.3 $\left.\mathrm{MHz}, \mathrm{CDCl}_{3}\right)$ : 12.56 .

(Z)-Docos-13-enyl Ester of 1-\{[(5S)-2-Hydroxy-2-oxido-1,4,2dioxaphosphinan-5-yl]methyl\}-5-azacytosine (4). Yield: $173 \mathrm{mg}$, $50 \%$ of a white solid $(50 \mathrm{mg}$ of $\mathbf{4 a}, 70 \mathrm{mg}$ of $\mathbf{4 b}, 53 \mathrm{mg}$ of diastereoisomeric mixture 4). Anal. $\left(\mathrm{C}_{29} \mathrm{H}_{53} \mathrm{~N}_{4} \mathrm{O}_{5} \mathrm{P} .1 .5 \mathrm{H}_{2} \mathrm{O}\right) \mathrm{C}, \mathrm{H}$, N, P. FABMS: $569.5(15)(\mathrm{MH})^{+}, 263.1(24)\left(\mathrm{M}-\mathrm{C}_{22} \mathrm{H}_{43}+2 \mathrm{H}\right)^{+}$ HRMS (FAB): For $\mathrm{C}_{29} \mathrm{H}_{54} \mathrm{~N}_{4} \mathrm{O}_{5} \mathrm{P}\left(\mathrm{MH}^{+}\right)$calculated: 569.3832; found: 569.3852 . Major diastereoisomer (trans): ${ }^{31} \mathrm{P}\left({ }^{1} \mathrm{H}\right.$ dec $) \mathrm{NMR}$ (202.3 MHz, $\left.\mathrm{CDCl}_{3}\right)$ : 10.77. Minor diastereoisomer (cis): ${ }^{31} \mathrm{P}\left({ }^{1} \mathrm{H}\right.$ dec) NMR (202.3 MHz, $\left.\mathrm{CDCl}_{3}\right)$ : 12.67.

2-(Hexadecyloxy)ethyl Ester of 1-\{[(5S)-2-Hydroxy-2-oxido1,4,2-dioxaphosphinan-5-yl]methyl $\}$-5-azacytosine (5). Product crystallized from methanol, mother liquors additionally purified by preparative reverse phase HPLC (Luna Phenomenex column, gradient $10-90 \%$ methanol in 20 min elution of tetrabutylammonium salts, then $100 \%$ methanol elution of 5). Yield $172 \mathrm{mg}, 53 \%$ of a white solid, diastereoisomers in ratio 3:2. Anal. $\left(\mathrm{C}_{25} \mathrm{H}_{47} \mathrm{~N}_{4} \mathrm{O}_{6} \mathrm{P}\right)$ C, H, N, P. ESIMS: $1061.1(2 \mathrm{M}+\mathrm{H})^{+}(13), 553.3(\mathrm{M}+\mathrm{Na})^{+}(45)$, $531.3(72)(\mathrm{MH})^{+}$. HRMS (QTOF): For $\mathrm{C}_{25} \mathrm{H}_{48} \mathrm{~N}_{4} \mathrm{O}_{6} \mathrm{P}\left(\mathrm{MH}^{+}\right)$ calculated: 531.3311; found: 531.3290. Major diastereoisomer (trans): ${ }^{31} \mathrm{P}\left({ }^{1} \mathrm{H} \mathrm{dec}\right) \mathrm{NMR}\left(202.3 \mathrm{MHz}, \mathrm{CDCl}_{3}\right)$ : 11.43. Minor diastereoisomer (cis): ${ }^{31} \mathrm{P}\left({ }^{1} \mathrm{H} \mathrm{dec}\right) \mathrm{NMR}\left(202.3 \mathrm{MHz}, \mathrm{CDCl}_{3}\right)$ : 13.60.

Pivaloyloxymethyl Ester of 1- $\{[(5 S)$-2-Hydroxy-2-oxido-1,4,2dioxaphosphinan-5-yl]methyl $\}$-5-azacytosine (Cyclic POMHPMP-azaC) (6). Purified by reverse phase HPLC (column Luna Phenomenex, 20\% methanol isocratically). Yield $119 \mathrm{mg}, 52 \%$ of a white solid foam. Anal. $\left(\mathrm{C}_{13} \mathrm{H}_{21} \mathrm{~N}_{4} \mathrm{O}_{7} \mathrm{P}\right) \mathrm{C}, \mathrm{H}, \mathrm{N}, \mathrm{P}$. Major diastereoisomer (trans): ${ }^{1} \mathrm{H} \mathrm{NMR}\left(600 \mathrm{MHz}, \mathrm{CDCl}_{3}\right): 1.25(\mathrm{~s}, 8 \mathrm{H}$, $\left.\left(\mathrm{CH}_{3}\right)_{3} \mathrm{C}\right) ; 3.49$ (dd, $\left.1 \mathrm{H}, J_{\text {gem }}=14.1, J_{1^{\prime} \mathrm{b}, 2^{\prime}}=7.7, \mathrm{H}-1^{\prime} \mathrm{b}\right) ; 3.98(\mathrm{~d}$, $\left.1 \mathrm{H}, J_{\mathrm{gem}}=14.8, \mathrm{CH}_{\mathrm{ax}} \mathbf{H}_{\mathrm{eq}} \mathrm{P}\right) ; 4.09\left(\mathrm{ddt}, 1 \mathrm{H}, J_{2^{\prime}, 1^{\prime}}=7.7,2.6, J_{2^{\prime}, 3^{\prime}}=\right.$ $\left.10.5,2.3, \mathrm{CH}-2^{\prime}\right) ; 4.12\left(\mathrm{dd}, 1 \mathrm{H}, J_{\mathrm{gem}}=14.1, J_{1^{\prime} \mathrm{a}, 2^{\prime}}=2.6, \mathrm{H}-1^{\prime} \mathrm{a}\right)$; $4.18\left(\mathrm{dd}, 1 \mathrm{H}, J_{\text {gem }}=14.8, J_{\mathrm{H}, \mathrm{P}}=11.2, \mathrm{CH}_{\mathrm{ax}} \mathrm{H}_{\mathrm{eq}} \mathrm{P}\right) ; 4.26(\mathrm{ddd}, 1 \mathrm{H}$, $\left.J_{\text {gem }}=11.8, J_{3^{\prime} \mathrm{ax}, 2^{\prime}}=10.5, J_{\mathrm{H}, \mathrm{P}}=1.4, \mathrm{H}-3^{\prime} \mathrm{ax}\right) ; 4.42\left(\mathrm{ddd}, 1 \mathrm{H}, J_{\mathrm{H}, \mathrm{P}}\right.$ $=17.3, J_{\text {gem }}=11.8, J_{3^{\prime} \text { eq }, 2^{\prime}}=2.3, \mathrm{H}^{\prime} 3^{\prime}$ eq $) ; 5.72\left(\mathrm{dd}, 1 \mathrm{H}, J_{\mathrm{H}, \mathrm{P}}=\right.$ $\left.11.9, J_{\text {gem }}=5.2, \mathrm{OCH}_{\mathrm{a}} \mathbf{H}_{\mathrm{b}} \mathrm{O}\right) ; 5.75\left(\mathrm{dd}, 1 \mathrm{H}, J_{\mathrm{H}, \mathrm{P}}=14.1, J_{\mathrm{gem}}=\right.$ 5.2, $\left.\mathrm{OCH}_{\mathrm{a}} \mathrm{H}_{\mathrm{b}} \mathrm{O}\right) ; 6.22$ and $7.29\left(2^{\prime} \mathrm{bs}, 2 \mathrm{H}, \mathrm{NH}_{2}\right) ; 7.93(\mathrm{~s}, 1 \mathrm{H}, \mathrm{H}-6)$. ${ }^{1} \mathrm{H}$ NMR (500 MHz, DMSO- $\left.d_{6}\right): 1.18\left(\mathrm{~s}, 8 \mathrm{H},\left(\mathrm{CH}_{3}\right)_{3} \mathrm{C}\right) ; 3.61$ (dd, $\left.1 \mathrm{H}, J_{\mathrm{gem}}=14.3, J_{1^{\prime} \mathrm{b}, 2^{\prime}}=7.5, \mathrm{H}-1^{\prime} \mathrm{b}\right) ; 3.87\left(\mathrm{dd}, 1 \mathrm{H}, J_{\mathrm{gem}}=14.3\right.$, $\left.J_{1^{\prime} \mathrm{a}, 2^{\prime}}=3.4, \mathrm{H}-1^{\prime} \mathrm{a}\right) ; 4.02\left(\mathrm{ddt}, 1 \mathrm{H}, J_{2^{\prime}, 1^{\prime}}=7.5,3.4, J_{2^{\prime}, 3^{\prime}}=10.6\right.$, $\left.2.0, \mathrm{H}-2^{\prime}\right) ; 4.05\left(\mathrm{~d}, 1 \mathrm{H}, J_{\mathrm{gem}}=14.9, \mathrm{CH}_{\mathrm{ax}} \mathbf{H}_{\mathrm{eq}} \mathrm{P}\right) ; 4.10(\mathrm{ddd}, 1 \mathrm{H}$, $\left.J_{\text {gem }}=11.7, J_{3^{\prime} \mathrm{ax}, 2^{\prime}}=10.6, J_{\mathrm{H}, \mathrm{P}}=1.3, \mathrm{H}-3^{\prime} \mathrm{ax}\right) ; 4.24\left(\mathrm{dd}, 1 \mathrm{H}, J_{\text {gem }}\right.$ $\left.=14.9, J_{\mathrm{H}, \mathrm{P}}=11.0, \mathrm{CH}_{\mathrm{ax}} \mathrm{H}_{\mathrm{eq}} \mathrm{P}\right) ; 4.41\left(\mathrm{ddd}, 1 \mathrm{H}, J_{\mathrm{H}, \mathrm{P}}=17.4, J_{\mathrm{gem}}\right.$ $\left.=11.7, J_{3^{\prime} \text { eq }, 2^{\prime}}=2.0, \mathrm{H}^{\prime} 3^{\prime} \mathrm{eq}\right) ; 5.66\left(\mathrm{dd}, 2 \mathrm{H}, J_{\mathrm{H}, \mathrm{P}}=13.3, \mathrm{OCH}_{2} \mathrm{O}\right)$; 7.45 and 7.46 (2' bs, $\left.2 \mathrm{H}, \mathrm{NH}_{2}\right) ; 8.09$ (s, 1H, H-6). ${ }^{13} \mathrm{C}$ NMR (151 $\left.\mathrm{MHz}, \mathrm{CDCl}_{3}\right): 26.77\left(\left(\mathrm{CH}_{3}\right)_{3} \mathrm{C}\right) ; 38.71\left(\mathrm{C}\left(\mathrm{CH}_{3}\right)_{3}\right) ; 46.64\left(\mathrm{CH}_{2-}\right.$ $\left.1^{\prime}\right) ; 64.08\left(\mathrm{~d}, J_{\mathrm{C}, \mathrm{P}}=144, \mathrm{CH}_{2} \mathrm{P}\right) ; 72.21\left(\mathrm{~d}, J_{\mathrm{C}, \mathrm{P}}=9, \mathrm{CH}_{2}-3^{\prime}\right) ; 73.19$ $\left(\mathrm{d}, J_{\mathrm{C}, \mathrm{P}}=5, \mathrm{CH}-2^{\prime}\right) ; 81.43\left(\mathrm{~d}, J_{\mathrm{C}, \mathrm{P}}=6, \mathrm{OCH}_{2} \mathrm{O}\right) ; 154.18(\mathrm{C}-2)$; 159.01 (CH-6); 166.43 (C-4); 176.96 (CO). ${ }^{31} \mathrm{P} \quad\left({ }^{1} \mathrm{H} \quad \mathrm{dec}\right)$ NMR (202.3 MHz, $\mathrm{CDCl}_{3}$ ): 10.80. Minor diastereoisomer (cis): ${ }^{1} \mathrm{H}$ NMR $\left(500 \mathrm{MHz}, \mathrm{CDCl}_{3}\right): 1.22\left(\mathrm{~s}, 8 \mathrm{H},\left(\mathrm{CH}_{3}\right)_{3} \mathrm{C}\right) ; 3.67(\mathrm{dd}$, $\left.1 \mathrm{H}, J_{\text {gem }}=13.8, J_{1^{\prime}} \mathrm{b}, 2^{\prime}=7.9, \mathrm{H}-1^{\prime} \mathrm{b}\right) ; 3.88\left(\mathrm{dd}, 1 \mathrm{H}, J_{\text {gem }}=14.1\right.$, $\left.J_{\mathrm{H}, \mathrm{P}}=1.9, \mathrm{CH}_{\mathrm{ax}} \mathbf{H}_{\mathrm{eq}} \mathrm{P}\right) ; 4.11\left(\mathrm{~m}, 1 \mathrm{H}, \mathrm{H}-2^{\prime}\right) ; 4.13\left(\mathrm{~m}, 1 \mathrm{H}, \mathrm{H}-1^{\prime} \mathrm{a}\right)$; $4.29\left(\mathrm{dd}, 1 \mathrm{H}, J_{\mathrm{gem}}=14.1, J_{\mathrm{H}, \mathrm{P}}=9.4, \mathrm{CH}_{\mathrm{ax}} \mathrm{H}_{\mathrm{eq}} \mathrm{P}\right) ; 4.45(\mathrm{~m}, 2 \mathrm{H}$, H-3'); $5.60\left(\mathrm{dd}, 1 \mathrm{H}, J_{\mathrm{H}, \mathrm{P}}=12.2, J_{\text {gem }}=5.2, \mathrm{OCH}_{\mathrm{a}} \mathbf{H}_{\mathrm{b}} \mathrm{O}\right) ; 5.77(\mathrm{dd}$, $\left.1 \mathrm{H}, J_{\mathrm{H}, \mathrm{P}}=13.8, J_{\mathrm{gem}}=5.2, \mathrm{OCH}_{\mathrm{a}} \mathrm{H}_{\mathrm{b}} \mathrm{O}\right) ; 6.45$ and $7.19\left(2^{\prime} \mathrm{bs}, 2 \mathrm{H}\right.$, $\left.\mathrm{NH}_{2}\right) ; 8.04$ (s, 1H, H-6). ${ }^{13} \mathrm{C} \mathrm{NMR}\left(125.7 \mathrm{MHz}, \mathrm{CDCl}_{3}\right): 26.71$ $\left(\left(\mathrm{CH}_{3}\right)_{3} \mathrm{C}\right) ; 38.62\left(\mathbf{C}\left(\mathrm{CH}_{3}\right)_{3}\right) ; 46.61\left(\mathrm{CH}_{2} \mathbf{1}^{\prime}\right) ; 64.39\left(\mathrm{~d}, J_{\mathrm{C}, \mathrm{P}}=147\right.$, $\left.\mathrm{CH}_{2} \mathrm{P}\right) ; 70.84\left(\mathrm{~d}, J_{\mathrm{C}, \mathrm{P}}=6, \mathrm{CH}_{2}-3^{\prime}\right) ; 72.87$ (d, $\left.J_{\mathrm{C}, \mathrm{P}}=4, \mathrm{CH}-2^{\prime}\right)$; $81.77\left(\mathrm{~d}, J_{\mathrm{C}, \mathrm{P}}=5, \mathrm{OCH}_{2} \mathrm{O}\right) ; 154.27(\mathrm{C}-2) ; 159.16(\mathrm{CH}-6)$; 166.43 (C-4); 176.94 (CO). ${ }^{31} \mathrm{P}\left({ }^{1} \mathrm{H} \mathrm{dec}\right) \mathrm{NMR}(202.3 \mathrm{MHz}$, $\left.\mathrm{CDCl}_{3}\right): 13.05$.
Reaction of 1 with Chloromethyl Pivalate. A suspension of $\mathbf{1}$ (100 mg; $0.36 \mathrm{mmol})$ in dry DMF (4 mL) was evaporated to $1 / 2$ of its original volume. $N, N$ '-dicyclohexyl-4-morpholinecarboxamidine $(200 \mathrm{mg}, 0.68 \mathrm{mmol}$ ) followed by chloromethyl pivalate (275 mg; $1.83 \mathrm{mmol}$ ) were added and the mixture was stirred for $72 \mathrm{~h}$ at $25^{\circ} \mathrm{C}$. The mixture was evaporated, the residue coevaporated with xylene $(4 \mathrm{~mL})$ and chromatographed on preparative TLC silica gel plate $(40 \times 17 \mathrm{~cm})$ in the system ethyl acetate-acetoneethanol-water (15:3:4:3). An appropriate band of silica gel $\left(\mathrm{R}_{\mathrm{F}}\right.$ 0.75) was separated, eluted with methanol, and filtered through Celite pad followed by filtration through nylon membrane filter (Whatman $0.2 \mu \mathrm{m}$ ). The filtrate was evaporated to give $38 \mathrm{mg}$ of a mixture of POM esters $\mathbf{6}$ and $\mathbf{7}$ as a white foam. FABMS: 509 (0.5) $\left(\mathrm{MH}^{+}\right.$of 7), 377 (1) $\left(\mathrm{MH}^{+}\right.$of 6), 294.2 (80) (Mpivaloyl $+2 \mathrm{H}^{+}$of 6), 86 (10) [pivaloyl]. HRMS (FAB): For $\mathrm{C}_{13} \mathrm{H}_{22} \mathrm{~N}_{4} \mathrm{O}_{7} \mathrm{P}\left(\mathrm{MH}^{+}\right.$of 6$)$ calculated: 377.1226; found: 377.1218 . HR MS (FAB): For $\mathrm{C}_{19} \mathrm{H}_{34} \mathrm{~N}_{4} \mathrm{O}_{10} \mathrm{P}\left(\mathrm{MH}^{+}\right.$of 7$)$ calculated: 509.2012; found: 509.2004 .

Reaction of 2 with Hexadecyloxyethanol. An Alternative Approach to Compound 5. A suspension of 2 (230 mg, 0.87 $\mathrm{mmol})$, hexadecyloxyethanol (260 mg, $0.9 \mathrm{mmol})$, DCC (300 mg, $1.5 \mathrm{mmol}$ ), and dimethylaminopyridine (catalytic amount, approximately $5 \mathrm{mg}$ ) in dry DMF $(5 \mathrm{~mL})$ was stirred at $110^{\circ} \mathrm{C}$ for $20 \mathrm{~h}$. After cooling to room temperature, the mixture was diluted with water $(10 \mathrm{~mL})$ and applied onto a column of Dowex $1\left(\mathrm{AcO}^{-}\right.$ form, $25 \mathrm{~mL})$. The column was eluted with acetone $(200 \mathrm{~mL})$, followed by water $(200 \mathrm{~mL})$. The combined UV absorbing elutes were evaporated and the residue chromatographed on preparative silica gel plate $(12 \times 25 \mathrm{~cm})$ in the system chloroformmethanol (85:15). Yield: $30 \mathrm{mg}, 6.5 \%$, white solid. The product was obtained as a mixture of two diastereoisomers (ratio 3:2). The unreacted starting compound was recovered from Dowex 1: the column was eluted first with $1 \mathrm{M}$ acetic acid $(250 \mathrm{~mL})$ to remove some impurities and degradation products; the pure cyclic phosphonate 2 was eluted with $1 \mathrm{M}$ formic acid. Appropriate fractions were evaporated, coevaporated with water $(4 \times 30 \mathrm{~mL})$ and with absolute ethanol $(50 \mathrm{~mL})$, and dried in vacuo to give $150 \mathrm{mg}(65 \%)$ of 2.

Antiviral Activity Assays. The compounds were evaluated against the following viruses: herpes simplex virus type 1 (HSV1) strain KOS, thymidine kinase-deficient $\left(\mathrm{TK}^{-}\right) \mathrm{HSV}-1 \mathrm{KOS}$ strain resistant to $\mathrm{ACV}\left(\mathrm{ACV}^{\mathrm{r}}\right)$, herpes simplex virus type 2 (HSV-2) strains Lyons and G, varicella-zoster virus (VZV) strain Oka, TK ${ }^{-}$ VZV strain 07-1, human cytomegalovirus (HCMV) strains AD169 and Davis, a clinical isolate of adenovirus type 2 (Ad2), human herpes virus 6 subtype A (HHV-6A) strain GS and subtype B (HHV-6B) strain Z29, vaccinia virus Lederle strain, respiratory syncytial virus (RSV) strain Long, vesicular stomatitis virus (VSV), Coxsackie B4, Parainfluenza 3, Reovirus-1, Sindbis, Reovirus-1, Punta Toro, human immunodeficiency virus type 1 strain IIIB, human immunodeficiency virus type 2 strain ROD, and hepatitis $\mathrm{C}$ virus (HCV). The antiviral, other than anti-HIV, assays were based on inhibition of virus-induced cytopathicity or plaque formation in human embryonic lung (HEL) fibroblasts, African green monkey cells (Vero), human epithelial cells (HeLa) or human T-lymphoblasts HSB-2, and MOLT-3, according to previously established procedures. ${ }^{16}$ Confluent cell cultures in microtiter 96-well plates were inoculated with 100 CCID50 of virus ( $1 \mathrm{CCID}_{50}$ being the virus dose to infect $50 \%$ of the cell cultures) or with 20 plaque forming units (PFU). After a $1-2 \mathrm{~h}$ adsorption period, residual virus was removed, and the cell cultures were incubated in the presence of varying concentrations of the test compounds. Viral cytopathicity or plaque formation (VZV) was recorded as soon as it reached completion in the control virusinfected cell cultures that were not treated with the test compounds. Antiviral activity was expressed as the $\mathrm{EC}_{50}$ or concentration required to reduce virus-induced cytopathogenicity or viral plaque formation by $50 \%$.

Inhibition of HIV-Induced Cytopathicity in CEM Cells. The methodology for the anti-HIV assays has been described previously. ${ }^{17}$ Briefly, human CEM cell cultures $\left(\sim 3 \times 10^{5}\right.$ cells $\left.\mathrm{mL}^{-1}\right)$ 
were infected with $\sim 100$ CCID50 HIV-1 $\left(\mathrm{III}_{\mathrm{B}}\right)$ or HIV-2 (ROD) per $\mathrm{mL}$ and seeded in $200 \mu \mathrm{L}$-well microtiter plates, containing appropriate dilutions of the test compounds. After 4 days of incubation at $37{ }^{\circ} \mathrm{C}$, syncytia cell formation was examined microscopically in the CEM cell cultures.

Inhibition of Moloney Murine Sarcoma Virus (MSV)Induced Transformation of Murine C3H/3T3 Embryo Fibroblasts. The anti-MSV assay was performed as described previously. ${ }^{17}$ Murine $\mathrm{C} 3 \mathrm{H} / 3 \mathrm{~T} 3$ embryo fibroblast cells were seeded at 5 $\times 10^{5}$ cells $\mathrm{mL}^{-1}$ into $1-\mathrm{cm}^{2}$ wells of 48 -well microplates. Then, $24 \mathrm{~h}$ later, the cell cultures were infected with 80 focus-forming units of MSV (prepared from tumors induced following intramuscular inoculation of 3-day-old NMRI mice with MSV, as described previously ${ }^{18}$ ) for $90-120 \mathrm{~min}$ at $37^{\circ} \mathrm{C}$. The medium was then replaced by $1 \mathrm{~mL}$ of fresh medium containing various concentrations of the test compounds. After 6 days, transformation of the cell cultures was examined microscopically.

Cytotoxicity Assays. Cytotoxicity measurements were based on the inhibition of cell growth. HEL cells were seeded at a rate of 5 $\times 10^{3}$ cells/well into 96-well microtiter plates and allowed to proliferate for $24 \mathrm{~h}$. Then, medium containing different concentrations of the test compounds was added. After 3 days of incubation at $37{ }^{\circ} \mathrm{C}$, the cell number was determined with a Coulter counter. The cytostatic concentration was calculated as the $\mathrm{CC}_{50}$, or the compound concentration required to reduce cell proliferation by $50 \%$ relative to the number of cells in the untreated controls. $\mathrm{CC}_{50}$ values were estimated from graphic plots of the number of cells (percentage of control) as a function of the concentration of the test compounds. Alternatively, cytotoxicity of the test compounds was expressed as the minimum cytotoxic concentration (MCC) or the compound concentration that caused a microscopically detectable alteration of cell morphology.

Acknowledgment. This study was performed as a research project of the Institute of Organic Chemistry and Biochemistry, Academy of Sciences of the Czech Republic \# Z4 055 0506, and the Centre for New Antivirals and Antineoplastics 1M0508. We gratefully acknowledge the financial support of NIH (grant 1UC1 AI062540-01), the European Commission (René Descartes Prize-2001, grant HPAW-2002-100096), the Grant Agency of the Academy of Sciences (\# 1QS 400550501) and Gilead Sciences (Foster City, CA). Our thanks are also due to the staff of mass spectrometry (Dr J. Cvačka, Head) and analytical departments of the Institute (Dr L. Holasová, Head) and Ms. Julie Křelinová for excellent technical assistance. We thank Ann Absilis, Anita Camps, Steven Carmans, Frieda De Meyer, Katrien Geerts, Leentje Persoons, Wim Van Dam, and Lies Van den Heurck for excellent technical assistance with the antiviral assays and Christiane Callebaut for invaluable editorial assistance.

Supporting Information Available: H,H-ROESY of trans-6, copies of NMR spectra, ${ }^{1} \mathrm{H}$ and ${ }^{13} \mathrm{C}$ NMR spectral data of esters 3-5 and elemental analysis data. This material is available free of charge via the Internet at http://pubs.acs.org.

\section{References}

(1) (a) Holý, A. Phosphonomethoxyalkyl analogs of nucleotides. Curr. Pharm. Design 2003, 9, 2567-2592. (b) De Clercq, E.; Holý, A. Acyclic nucleoside phosphonates: A key class of antiviral drugs. Nat. Rev. Drug Discovery 2005, 4, 928-940.

(2) (a) Hitchcock, M.J.; Jaffe, H.S.; Martin, J.C.; Stagg, R.J. Cidofovir, a new agent with potent anti-herpesvirus activity. Antivir. Chem. Chemother. 1996, 7, 115-127. (b) De Clercq, E. Towards an effective chemotherapy of virus infections: Therapeutic potential of cidofovir [(S)-1-[3-hydroxy-2-(phosphonomethoxy)propyl]cytosine, HPMPC] for the treatment of DNA virus infections. Collect. Czech. Chem. Соттип. 1998, 63, 480-506.
(3) Berenguer, J.; Mallolas, J. Intravenous cidofovir for compassionate use in AIDS patients with cytomegalovirus retinitis. Clin. Infect. Dis. 2000, 30, 182-184.

(4) (a) Kern, E. R.; Hartline, C.; Harden, E.; Keith, K.; Rodriguez, N.; Beadle, J. R.; Hostetler, K. Y. Enhanced inhibition of orthopoxvirus replication in vitro by alkoxyalkyl esters of cidofovir and cyclic cidofovir. Antimicrob. Agents Chemother. 2002, 46, 991-995. (b) Keith, K. A.; Hitchcock, M. J. M.; Lee, W. A.; Holý, A.; Kern, E. R. Evaluation of nucleoside phosphonates and their analogs and prodrugs for inhibition of orthopoxvirus replication. Antimicrob. Agents Chemother. 2003, 47, 2193-2198. (c) Keith, K. A.; Wan, W. B.; Ciesla, S. L.; Beadle, J. R.; Hostetler, K. Y.; Kern, E. R. Inhibitory activity of alkoxyalkyl and alkyl esters of cidofovir and cyclic cidofovir against orthopoxvirus replication in vitro. Antimicrob. Agents Chemother. 2004, 48, 1869-1871.

(5) (a) Krečmerová, M.; Masojídková, M.; Holý, A. Preparation of C-5 Substituted Cidofovir Derivatives. Collect. Czech. Chem. Commun. 2006, 71, 579-594. (b) Chalupová, S.; Holý, A.; Masojídková, M. Synthesis of some $N^{4}$-substituted derivatives of 1-[(S)-3-hydroxy-2phosphonomethoxy)propyl]cytosine (HPMPC, cidofovir). Collect. Czech. Chem. Commun. 2005, 70, 2053-2065.

(6) Krečmerová, M.; Holý, A.; Pískala, A.; Masojídková, M.; Balzarini, J.; Andrei, G.; Snoeck, R.; Naesens, L.; Neyts, J.; De Clercq, E. Triazine analogs of 1-(S)- [3-hydroxy-2-(phosphonomethoxy)propyl]cytosine (cidofovir) and related compounds. J. Med. Chem. 2007, 50, 1069-1077.

(7) (a) Naesens, L.; Neyts, J.; Balzarini, J.; Bischofberger, N.; De Clercq, E. In vivo antiretroviral efficacy of oral bis(POM)-PMEA, the bis(pivaloyloxymethyl)prodrug of 9-(2-phosphonylmethoxyethyl)adenine (PMEA). Nucleos. Nucleot. 1995, 14, 767-770. (b) Noble, S.; Goa, K. L. Adefovir dipivoxil. Drugs 1999, 58, 479-487.

(8) (a) Naesens, L.; Bischofberger, N.; Augustijns, P.; Annaert, P. Vandenmooter, G.; Arimilli, M. N. et al. Antiretroviral efficacy and pharmacokinetics of oral bis(isopropyloxy) 9-(2-phosphonylmethoxypropyl)adenine in mice. Antimicrob. Agents Chemother. 1998, 42 , 1568-1573. (b) Schooley, R .T.; Ruane, P.; Myers, R. A.; Beall, G.; Lampiris, H.; Berger, D. et al. Tenofovir DF in antiretroviral - experienced patients: results from a 48-week, randomized, doubleblind study. AIDS 2002, 16, 1257-1263.

(9) (a) Oliyai, R.; Arimilli, M. N.; Jones, R. J.; Lee, W. A. Pharmacokinetics of salicylate ester prodrugs of cyclic HPMPC in dogs. Nucleosides Nucleotides Nucleic Acids 2001, 20, 1411-1414. (b) Oliyai, R.; Shaw, J.-P.; Sueoka-Lennen, C. M.; Cundy, K. C.; Arimilli, M. N.; Jones, R. J.; Lee, W. A. Aryl ester prodrugs of cyclic HPMPC. I: Physicochemical characterization and in vitro biological stability. Pharm. Res. 1999, 16, 1687-1693.

(10) (a) Kern, E. R.; Hartline, C.; Harden, E.; Keith, K.; Rodriguez, N.; Beadle, J. R.; Hostetler, K. Y. Enhanced inhibition of orthopoxvirus replication in vitro by alkoxyalkyl esters of cidofovir and cyclic cidofovir. Antimicrob. Agents Chemother. 2002, 46, 991-995. (b) Hostetler, K. Y.; Beadle, J. R. Orally Active Lipid Esters of Antiviral Nucleoside Phosphonates. In Collection Symposium Series; Hocek, M., Ed.; Institute of Organic Chemistry and Biochemistry, Academy of Sciences of the Czech Republic: Prague, 2005; Vol. 7, pp 95103.

(11) Beadle, J. R.; Wan, W. B.; Ciesla, S. L.; Keith, K. A.; Hartline, C. Kern, E. R.; Hostetler, K. Y. Synthesis and antiviral evaluation of alkoxyalkyl derivatives of 9-(S)-(3-hydroxy-2-phosphonomethoxypropyl)adenine against cytomegalovirus and orthopoxviruses. $J$. Med. Chem. 2006, 49, 2010-2015.

(12) (a) Pit'hová, P.; Pískala, A.; Pit'ha, J.; Šorm, F. Nucleic acids components and their analogues. LXVI. Hydrolysis of 5-azacytidine and its connection with biological activity. Collect. Czech. Chem. Commun. 1965, 30, 2801-2811. (b) Benjamin. E.J. The chemistry of the degradation of 5-azacytidine and some derivatives of 5-azacytosine. Ph.D. Thesis. University of Kansas, 1979; Diss. Abstr. 1980, 41, 208-B.

(13) Starrett, J. E.; Tortolani, D. R.; Russell, J.; Hitchcock, M. J. M.; Whiterock, V.; Martin, J. C.; Mansuri, M. M. Synthesis, oral bioavailability determination, and in-vitro evaluation of prodrugs of the antiviral agent 9-[2-(phosphonomethoxy)ethyl]adenine (PMEA). J. Med. Chem. 1994, 37, 1857-1864.

(14) Carroll, K. K. Preparation of erucic and nervonic acids labelled with carbon-14. Can. J. Chem. 1957, 35, 757-760.

(15) Singh, R. S.; Mukherjee, K.; Banerjee, R.; Chaudhuri, A.; Hait, S. K.; Moulik, S. P.; Ramadas, Y.; Vijayalakshmi, A.; Rao, N. M. Anchor dependency for non-glycerol based cationic lipofectins: mixed bag of regular and anomalous transfection profiles. Chem.Eur. J. 2002, 8, 900-909.

(16) (a) De Clercq, E.; Descamps, J.; Verhelst, G; Walker, R. T.; Jones, A.S.; Torrence, P.F.; Shugar, D. Comparative efficacy of antiherpes drugs against different strains of herpes simplex virus. J. Infect. Dis. 1980, 141, 563-574. (b) De Clercq, E.; Sakuma, T.; Baba, M 
Pauwels, R.; Balzarini, J.; Rosenberg, I.; Holý, A. Antiviral activity of phosphonomethoxyalkyl derivatives of purine and pyrimidines. Antiviral Res. 1987, 8, 261-272. (c) De Bolle L.; Michel, D.; Mertens, T.; Manichanh, C.; Agut, H.; De Clercq, E.; Naesens, L. Role of the human herpesvirus 6 u69-encoded kinase in the phosphorylation of ganciclovir. Mol. Pharmacol. 2002, 62, 714721.

(17) Balzarini, J.; Naesens, L.; Slachmuylders, J.; Niphuis, H.; Rosenberg, I.; Holý, A.; Schellekens, H.; De Clercq, E. 9-(2-phosphonylmethoxyethyl)adenine (PMEA) effectively inhibits simian immunodeficiency virus (SIV) infection in Rhesus monkeys. AIDS 1991, 5, 21-28.

(18) Balzarini, J.; Naesens, L.; Herdewijn, P.; Rosenberg, I.; Holý, A.; Pauwels, R.; Baba, M.; Johns, D. G.; De Clercq, E. Marked in vivo antiretrovirus activity of 9-(2-phosphonylmethoxyethyl)adenine, a selective anti-human immunodeficiency virus agent. Proc. Natl. Acad. Sci. U.S.A. 1989, 86, 332-336.

JM0707166 